\title{
PENGETAHUAN GIZI, AKTIVITAS FISIK, KONSUMSI SNACK DAN PANGAN LAINNYA PADA MURID SEKOLAH DASAR DI BOGOR YANG BERSTATUS GIZI NORMAL DAN GEMUK
}

\author{
(Nutrition Knowledge, Physical Activity, Snack Consumption and Other Food in Normal and \\ Overweight of Elementary Students in Bogor) \\ Deni ${ }^{1}$ dan Cesilia Meti Dwiriani ${ }^{2 *}$ \\ 1 Departemen Gizi Masyarakat, Fakultas Ekologi Manusia, Institut Pertanian Bogor, Bogor 16680 \\ $2^{*}$ Alamat korespondensi: Departemen Gizi Masyarakat, Fakultas Ekologi Manusia, Institut Pertanian \\ Bogor, Bogor 16680. Tel: 0251-8621258; Fax: 0251-8622276; Email: erlangga259@yahoo.com
}

\begin{abstract}
Childhood obesity is increases rapidly in developing country. It's has important shortterm and long-term medical consequences also psychosocial consequences. The objective of the research is to analyze nutritional knowledge, physical activity, snack habit, in normal and overweight of Bina Insani elementary students in Bogor. The cross sectional study design was used in this study to analyze nutritional knowledge, snack habit, and physical activity in normal and overweight students. The total number of 80 students sample was chosen randomly. It consists of 40 students sample with normal nutritional status and 40 students sample with overweight nutritional status. Primary data consisted of physical activity recall (1×24 hours), food consumption recall ( $2 \times 24$ hours), anthropometry data (weight and height), social-economy's sample condition, food habit, and snack habit using Food Frequency Questionnaire (FFQ). Secondary data were included data of Bina Insani Elementary School. The result showed no relation between level education and wage of parent, nutritional knowledge level, nutritional attitude, snack habit and physical activity with nutritional status of sample. The average energy adequacy level according to WNPG (2004) respectively $82.2 \%$ in normal sample and $73.6 \%$ in overweight sample.
\end{abstract}

Keywords: nutritional knowledge, physical activity, snack habit, children, overweight.

\section{PENDAHULUAN}

Prevalensi obesitas makin meningkat, hampir setengah milyar penduduk saat ini tergolong overweight atau obes (Rossner, 2002). Keadaan ini tidak hanya terjadi di negara maju tapi sudah mulai meningkat di negara berkembang. Mengacu pada penelitian yang dilakukan oleh Padmiari (2004) terhadap 80 anak SD di Denpasar, diketahui bahwa 75\% konsumsi energi anak-anak tersebut berasal dari jajanan dan hanya $25 \%$ konsumsi energi anak-anak dipasok dari makanan pokok berupa nasi, daging, sayuran dan pelengkapnya.

Obesitas yang terjadi selama masa kanak-kanak memiliki konsekuensi medis jangka pendek, meliputi efek yang merugikan terhadap pertumbuhan. Konsekuensi medis jangka panjang meliputi risiko yang lebih besar untuk terkena hipertensi, diabetes, penyakit kardiovaskuler, dan osteoartitis pada masa dewasa. Obesitas pada masa anak-anak juga menimbulkan konsekuensi psikososial jangka pendek dan panjang seperti image diri yang negatif, penu- runan kepercayaan diri, gangguan makan, dan kesehatan yang lebih rendah hubungannya dengan kualitas hidup (Thorpe et al., 2004).

Anak usia sekolah dalam hal ini anak SD rentan terpengaruh oleh berbagai jajanan yang dijajakan baik di sekolah maupun di luar sekolah. Kondisi ini diperparah dengan maraknya iklan makanan ringan di televisi. Pada hari libur, anak-anak cenderung menghabiskan waktu dengan menonton televisi atau jalan-jalan ke mall dan memilih menghabiskan waktu luangnya dengan mengonsumsi snack dan sejenisnya. Pola aktivitas serta pola makan seperti ini sangat mengkhawatirkan, mengingat rendahnya aktivitas dan tingginya asupan makanan dapat berisiko menyebabkan obesitas dini pada anak. Oleh karena itu, peneliti tertarik untuk meneliti tentang pengetahuan gizi, aktivitas fisik, dan kebiasaan mengonsumsi snack serta pangan lainnya serta kejadian kegemukan pada anak sekolah dasar.

Tujuan dari penelitian ini ialah untuk mengetahui tingkat pengetahuan gizi, aktivitas fisik, kebiasaan mengonsumsi snack dan pa- 
ngan lainnya pada murid SD yang berstatus gizi normal dan gemuk di Kota Bogor.

\section{METODE PENELITIAN}

\section{Desain, Tempat, dan Waktu Penelitian}

Penelitian ini menggunakan desain crosssectional. Penelitian ini dilakukan di SD Bina Insani, yaitu sekolah dengan tingkat sosial ekonomi orang tua menengah ke atas. Pemilihan lokasi sekolah dasar dilakukan secara purposive. Penelitian ini berlangsung selama dua bulan, yaitu bulan April sampai dengan Mei 2009.

\section{Prosedur Penarikan Contoh}

Populasi contoh dalam penelitian ini adalah siswa kelas 4 dan 5 sekolah dasar. Pemilihan contoh dilakukan secara purposive berdasarkan izin dari pihak sekolah. Teknik penarikan contoh ditentukan berdasarkan IMT dengan mengukur berat badan dan tinggi badan. Setelah itu, dilihat status gizinya menurut IMT/U (Riyadi, 2003). Secara keseluruhan jumlah contoh yang diambil sebanyak 80 siswa, yaitu 40 siswa yang berstatus gizi normal dan $\mathbf{4 0}$ siswa yang berstatus gizi gemuk.

\section{J enis dan Cara Pengumpulan Data}

Jenis data yang dikumpulkan meliputi data primer dan data sekunder. Data primer meliputi karakteristik contoh, sosial ekonomi keluarga, pengetahuan gizi, recall konsumsi snack dan pangan lainnya, serta aktivitas fisik. Adapun data sekunder yang dikumpulkan meliputi keadaan umum sekolah.

Data primer dikumpulkan dengan menggunakan kuesioner, data berat badan dan tinggi badan diperoleh dengan cara pengukuran langsung dengan menggunakan timbangan injak digital dan microtoise. Adapun data mengenai keadaan umum sekolah diperoleh melalui informasi baik lisan maupun tulisan dari pihak Tata Usaha sekolah.

\section{Pengolahan dan Analisis Data}

Data yang dikumpulkan diolah dan dianalisis secara deskriptif dan inferensial menggunakan program Microsoft Excell dan SPSS 14.0 for Windows. Data pengetahuan gizi contoh diberi skor 1 jika jawaban pertanyaan benar dan skor 0 jika jawaban contoh salah, sehingga total skor adalah 20. Pengetahuan gizi contoh dikategorikan rendah jika kurang dari $60 \%$ jawaban benar, sedang jika antara $60-80 \%$ jawaban benar dan tinggi jika lebih dari $80 \%$ jawaban benar (Khomsan, 2000). Data mengenai sikap gizi contoh diberi skor 1 jika jawaban benar, skor -1 jika jawaban salah dan skor 0 jika menjawab ragu-ragu. Sikap gizi contoh dikategorikan rendah jika kurang dari $60 \%$ jawaban benar, sedang jika antara $60-80 \%$ jawaban benar dan tinggi jika lebih dari $80 \%$ jawaban benar (Khomsan et al., 2009).

Data konsumsi pangan individu yang dikumpulkan ditabulasi dan kemudian dirata-ratakan per bahan pangan hingga diperoleh ratarata per kelompok. Selanjutnya dikonversi ke dalam bentuk energi, protein, lemak dan karbohidrat dengan menggunakan Daftar Komposisi Bahan Makanan (DKBM 2008). Angka kecukupan energi contoh, dihitung dengan menggunakan rumus sebagai berikut :

$$
A K G i=(88.5-61.9 \times \text { Usia })+\left(26.7 \times \text { BB }^{*} \times 1.31\right)
$$
+903 TB +25

*Untuk contoh gemuk, digunakan berat badan ideal berdasarkan berat badan sehat anak usia sekolah (WNPG, 2004).

Angka kebutuhan dan kecukupan contoh diketahui setelah konsumsi energi dan zat-zat gizi diketahui, selanjutnya dihitung Tingkat Kecukupan Gizi (TKG) terutama energi dan protein bagi setiap individu. Pengukuran status gizi dilakukan dengan metode antropometri melalui perhitungan indeks IMT/U. Indeks IMT/U digunakan untuk anak yang berumur 924 tahun, dengan menggunakan persentil. Contoh dikategorikan kurus bila nilai IMT < persentil ke-5, normal bila nilai IMT antara persentil ke-5 s.d persentil ke-85 dan gemuk bila nilai IMT $\geq$ persentil ke-85.

Mengacu kepada Departemen Kesehatan (1996) yang mengklasifikasikan tingkat kecukupan energi dan protein kedalam lima tingkat, yaitu : (1) defisit tingkat berat $(<70 \%$ AKG), (2) defisit tingkat sedang (70-79\% AKG), (3) defisit tingkat ringan (80-89\% AKG), (4) Normal (90-119\% AKG) dan (5) Kelebihan ( $\geq 120 \%$ AKG). Hubungan antar variabel dianalisis dengan menggunakan uji korelasi Spearman, sedangkan perbedaan antar variabel menggunakan uji beda $\mathrm{t}$ (Independent Sample t-Test).

\section{HASIL DAN PEMBAHASAN}

\section{Karakteristik Contoh}

Jumlah contoh laki-laki dan perempuan pada contoh yang berstatus gizi gemuk adalah sama, sedangkan pada contoh berstatus gizi 
normal jumlah contoh laki-laki sedikit lebih kecil dibandingkan jumlah contoh perempuan. Contoh dalam penelitian ini berusia 9-11 tahun dan persentase terbesar pada usia 10 tahun pada kelompok normal (47.5\%) dan contoh gemuk tersebar pada usia 10 tahun (47.5\%) dan 11 tahun (47.5\%). Seluruh contoh beragama Islam. Sebagian besar contoh (41.2\%) baik pada contoh berstatus gizi normal maupun gemuk berasal dari etnis Jawa.

Sebagian besar contoh normal dan gemuk, mengeluarkan biaya untuk transportasi setiap bulan berkisar antara Rp 150000 - Rp 300 000, dengan rata-rata sebesar Rp 142 $062.50 \pm 90$ 946.00. Hasil uji statistik (Independent Sample t-Test) menunjukkan tidak terdapat perbedaan yang nyata antara kedua contoh $(p=0.169)$. Sebagian besar contoh baik yang normal (52.5\%) maupun yang gemuk (67.5\%) memper-oleh uang saku yang berkisar antara Rp90 000 - 180 000/bulan, dengan ratarata adalah Rp $186750 \pm 97$ 439. Hasil uji statistik (Independent Sample t-Test) menunjukkan tidak ada perbe-daan yang nyata antara besar uang saku pada kedua contoh $(p=0.276)$.

\section{Karakteristik Keluarga Contoh}

Bagian terbesar contoh normal (47.5\%) dan contoh gemuk (42.5\%) berasal dari keluarga sedang (5-6 orang). Hasil analisis Korelasi Spearman menunjukkan tidak terdapat hubungan yang signifikan antara jumlah anggota keluarga dengan status gizi contoh $(p=0.688)$. Sebesar $52.5 \%$ ayah contoh normal berstatus gizi normal (dilihat dari nilai IMT). Begitu pula dengan status gizi ibu. Sebagian besar ibu contoh normal (75\%) memiliki status gizi normal. Pada contoh gemuk, diketahui bahwa sebagian besar ayah (55\%) berstatus gizi normal. Begitu juga dengan status gizi ibu contoh dimana sebesar $57.5 \%$ ibu con-toh gemuk berstatus gizi normal.

Sebagian besar pada contoh normal (62.5\%) dan gemuk (60\%) tidak memiliki saudara kandung yang gemuk. Sementara itu, ketika ditanyakan lebih lanjut baik pada contoh normal maupun gemuk yang menyatakan memiliki saudara kandung yang berstatus gizi gemuk, diketahui sebesar $62.5 \%$ contoh gemuk dan $66.7 \%$ contoh normal memiliki jumlah saudara kandung (adik/kakak) yang gemuk sebanyak satu orang. Sisanya pada kedua kelompok contoh memiliki saudara kandung yang gemuk sebanyak dua orang. Hasil analisis Korelasi Spearman menunjukkan adanya hubungan yang signifikan antara jumlah saudara kandung yang gemuk dengan status gizi contoh $(p=0.001)$.
Hal ini berarti semakin banyak saudara kandung yang gemuk, maka status gizi contoh juga semakin mendekati gemuk.

\section{Kondisi Sosial Ekonomi Keluarga}

Sebagian besar ayah contoh berpendidikan terakhir Strata 1 (S1) dan S2. Begitu juga pendidikan ibu. Sebesar $42.5 \%$ ibu contoh normal dan sebesar $52.5 \%$ ibu contoh gemuk berpendidikan terakhir S1. Sebagian besar penghasilan ayah kurang dari sepuluh juta rupiah dan penghasilan ibu kurang dari tiga juta rupiah. Berdasarkan hasil kuesioner yang diberikan kepada orang tua contoh, diketahui bahwa rata-rata besar pendapatan ayah contoh adalah sebesar Rp $9903750 \pm 9307$ 346, sedangkan rata-rata pendapatan ibu contoh adalah Rp $2503750 \pm 3501950$.

Persentase tingkat pendapatan ayah contoh yang gemuk dengan kategori sedang ke atas lebih tinggi dibandingkan dengan contoh normal. Hal ini sesuai dengan hasil penelitian Padmiari dan Hadi, 2003 dalam Indraaryani, 2009, yang menunjukkan bahwa kejadian obesitas terdapat pada keluarga yang mempunyai pendapatan yang tinggi atau golongan menengah ke atas. Hasil uji statistik (Independent Sample t-Test) menunjukkan tidak ada perbedaan yang nyata antara kedua contoh $(p>0.05)$. Hasil analisis Korelasi Spearman juga menunjukkan tidak adanya hubungan yang signifikan antara tingkat pendidikan dan penghasilan orang tua dengan status gizi contoh $(p>0.05)$.

\section{Tingkat Pengetahuan dan Sikap Gizi}

Secara keseluruhan, $40 \%$ contoh memiliki tingkat pengetahuan gizi rendah, $43.8 \%$ contoh memiliki tingkat pengetahuan gizi sedang dan hanya $16.2 \%$ contoh yang memiliki tingkat pengetahuan gizi yang tinggi (Tabel 1).

Tabel 1. Sebaran Contoh berdasarkan Tingkat Pengetahuan Gizi dan Sikap Gizi

\begin{tabular}{|c|c|c|c|c|c|c|}
\hline \multirow{3}{*}{ Kategori } & \multicolumn{6}{|c|}{ Status Gizi } \\
\hline & \multicolumn{2}{|c|}{ Normal } & \multicolumn{2}{|c|}{ Gemuk } & \multicolumn{2}{|c|}{ Total } \\
\hline & $\mathbf{n}$ & $\%$ & $\mathbf{n}$ & $\%$ & $\mathbf{n}$ & $\%$ \\
\hline \multicolumn{7}{|c|}{ Tingkat Pengetahuan Gizi } \\
\hline Tinggi & 6 & 15.0 & 7 & 17.5 & 13 & 16.2 \\
\hline Sedang & 15 & 37.5 & 20 & 50.0 & 35 & 43.8 \\
\hline Rendah & 19 & 47.5 & 13 & 32.5 & 32 & 40.0 \\
\hline Total & 40 & 100 & 40 & 100 & 80 & 100 \\
\hline \multicolumn{7}{|c|}{ Tingkat Pemahaman Sikap Gizi } \\
\hline Tinggi & 11 & 27.5 & 9 & 22.5 & 20 & 25.0 \\
\hline Sedang & 22 & 55.0 & 20 & 50.0 & 42 & 52.5 \\
\hline Rendah & 7 & 17.5 & 11 & 27.5 & 18 & 22.5 \\
\hline Total & 40 & 100 & 40 & 100 & 80 & 100 \\
\hline
\end{tabular}


Hasil analisis Korelasi Spearman menunjukkan tidak adanya hubungan yang signifikan antara tingkat pengetahuan gizi dengan status gizi contoh $(p>0.05)$. Sebagian besar contoh normal memiliki sikap gizi sedang (55\%). Begitu juga pada contoh gemuk, sebesar $50 \%$ contoh memiliki tingkat sikap gizi sedang. Hasil uji statistik (Independent Sample t-test) menunjukkan tidak ada perbedaan yang nyata pada tingkat pengetahuan gizi $(p=0.184)$ dan sikap gizi kedua kelompok contoh $(p=0.957)$. Hasil analisis Korelasi Spearman menunjukkan tidak adanya hubungan yang signifikan antara tingkat pemahaman sikap gizi dengan status gizi contoh $(p>0.05)$.

\section{Aktivitas Fisik Contoh}

Sebanyak lebih dari $80 \%$ contoh normal ataupun gemuk menyatakan biasa melakukan olahraga. Jenis olahraga yang paling banyak dilakukan adalah sepakbola. Frekuensi olah raga dalam satu minggu rata-rata dilakukan oleh contoh sebanyak 2-4 kali (58.6\%) dengan durasi/lama waktu berolahraga rata-rata 15-30 menit (54.3\%). Seluruh contoh normal dan hampir seluruh contoh gemuk mengikuti kegiatan ekstrakurikuler di sekolah. Pada contoh normal kegiatan ekstrakurikuler yang paling banyak diikuti adalah Kelompok Ilmiah Anak (KIA) (30\%) dan sepak bola (17.5\%). Begitu juga pada contoh gemuk, kegiatan ekstrakurikuler yang paling banyak diikuti oleh contoh adalah KIA (25.6\%) dan sepak bola (15.4\%). Hasil uji statistik (Independent Sample t-Test) menunjukkan tidak terdapat perbedaan yang nyata antara kedua kelompok contoh dalam hal jenis ekstrakurikuler yang diikuti $(p>0.05)$. Hasil analisis korelasi Spearman juga menunjukkan tidak adanya hubungan yang signifikan antara frekuensi olahraga, lama berolahraga, dan jenis ekstrakurikuler yang diikuti dengan status gizi contoh $(p>0.05)$.

\section{Kebiasaan Makan Contoh}

Sebesar $82.5 \%$ contoh normal dan sebesar $75 \%$ contoh gemuk terbiasa makan tiga kali sehari. Lebih dari $80 \%$ contoh baik pada contoh gemuk ataupun normal terbiasa melakukan sarapan sebelum berangkat ke sekolah. Sebesar 63.6\% pada contoh normal dan sebesar $65.6 \%$ pada contoh gemuk biasa mengonsumsi nasi dan lauk pauk sebagai menu pada saat sarapan. Hasil analisis Korelasi Spearman menunjukkan tidak ada hubungan yang signifikan antara frekuensi makan, kebiasaan sarapan, dan jenis makanan yang dikonsumsi saat sarapan dengan status gizi $(p>0.05)$.
Sebesar $67.5 \%$ contoh normal dan sebesar $87.5 \%$ contoh gemuk terbiasa minum susu setiap hari. Rata-rata sebagian besar contoh mengonsumsi susu sebanyak satu gelas setiap hari (61.8\%). Berdasarkan hasil uji statistik (Independent Sample t-Test), diketahui terdapat perbedaan yang nyata antara jumlah susu yang biasa diminum setiap hari pada kedua kelompok contoh $(p=0.046)$ dimana contoh gemuk lebih banyak yang mengonsumsi susu satu gelas setiap harinya dibandingkan dengan contoh normal. Hasil analisis Korelasi Spearman menunjukkan tidak adanya hubungan yang signifikan antara kebiasaan minum susu dengan status gizi $(p>0.05)$.

Sebagian besar contoh normal terbiasa membawa bekal, sedangkan pada contoh gemuk sebesar $65 \%$ contoh tidak terbiasa membawa bekal ke sekolah. Hasil analisis Korelasi Spearman menunjukkan terdapat hubungan negatif yang signifikan antara kebiasaan membawa bekal dengan besar uang saku ( $\mathrm{p}=$ $0.037)$. Artinya bahwa apabila contoh membawa bekal maka kemungkinan uang saku yang dibawa/diberikan semakin kecil. Contoh normal maupun contoh gemuk ternyata terbiasa makan siang di kantin (jajan). Hasil uji statistik (Independent Sample t-Test) menunjukkan tidak terdapat perbedaan yang nyata antara kedua contoh $(p>0.05)$.

\section{Kebiasaan Mengonsumsi Snack}

Snack jenis biskuit adalah yang paling sering dikonsumsi oleh kedua contoh dengan frekuensi tersering 1-3x bulan. Pizza adalah jenis fast food yang paling banyak pernah dikonsumsi oleh kedua contoh dengan frekuensi tersering $1-3 x /$ bulan dan minuman ringan berkarbonasi adalah jenis minuman ringan yang paling sering dkonsumsi oleh kedua contoh. Hasil analisis Korelasi Spearman menunjukkan tidak adanya hubungan yang signifikan antara kebiasaan mengonsumsi snack, soft drink dan fast food dengan status gizi contoh ( $p>0.05)$. Hasil analisis Korelasi Spearman juga menunjukkan tidak adanya hubungan yang signifikan antara kebiasaan mengonsumsi snack, soft drink dan fast food dengan tingkat pengetahuan gizi dan pemahaman sikap gizi contoh $(p>0.05)$.

\section{Intik Konsumsi dan Tingkat Kecukupan Gizi}

Pada contoh normal, rata-rata asupan energi adalah 1519 Kalori dan rata-rata asupan protein sebesar $41.3 \mathrm{~g}$. Sementara itu, ratarata asupan lemak dan karbohidratnya adalah 40.6 g dan 236.5 g. Pada contoh gemuk, rata- 
rata asupan energi adalah sebesar 1479 Kalori, rata-rata asupan protein sebesar $41.0 \mathrm{~g}$, ratarata asupan lemak dan karbohidrat adalah 41.6 g dan 220.8 g. Berdasarkan data tersebut, maka diperoleh rata-rata Tingkat Kecukupan Gizi (TKG) energi sebesar $82.2 \%$ dan protein sebesar $90.7 \%$ pada contoh normal, sedangkan pada contoh gemuk, diperoleh rata-rata TKG energi sebesar $73.6 \%$ dan protein sebesar $89.3 \%$ (Tabel 2).

Tabel 2. Rata-rata Konsumsi, Kecukupan dan Tingkat Kecukupan Energi dan Zat Gizi Menurut Status Gizi

\begin{tabular}{|c|c|c|}
\hline \multirow{2}{*}{ Energi dan Zat Gizi } & \multicolumn{2}{|c|}{ Rata-rata } \\
\hline & Normal & Gemuk \\
\hline \multicolumn{3}{|l|}{ Energi } \\
\hline Konsumsi (kkal) & 1519 & 1479 \\
\hline Kecukupan (kkal) & 1848 & 2009 \\
\hline Tingkat Konsumsi (\%) & 82.2 & 73.6 \\
\hline \multicolumn{3}{|l|}{ Protein } \\
\hline Konsumsi (g) & 41.3 & 41 \\
\hline Kecukupan (g) & 45.5 & 45.9 \\
\hline Tingkat Konsumsi (\%) & 90.7 & 89.3 \\
\hline \multicolumn{3}{|l|}{ Lemak } \\
\hline Konsumsi (g) & 41.5 & 41.6 \\
\hline Kecukupan (g) & 41.1 & 44.6 \\
\hline Tingkat Konsumsi (\%) & 101.0 & 93.3 \\
\hline \multicolumn{3}{|l|}{ Karbohidrat } \\
\hline Konsumsi (g) & 236.5 & 220.8 \\
\hline Kecukupan (g) & 323.4 & 351.5 \\
\hline Tingkat Konsumsi (\%) & 73.1 & 62.8 \\
\hline
\end{tabular}

Tingkat kecukupan energi pada kelompok contoh normal tergolong defisit tingkat ringan dan pada contoh gemuk tergolong defisit tingkat sedang. Tingkat kecukupan protein contoh normal tergolong normal, sedangkan pada contoh gemuk tergolong defisit tingkat ringan.

Sebagian besar contoh memenuhi kebutuhan makanan pokoknya dari nasi dan mie instant. Sementara itu, untuk memenuhi kebutuhan protein contoh lebih banyak dari pangan sumber protein hewani seperti daging ayam dan telur ayam. Konsumsi sayur dan buah contoh relatif masih kurang begitu juga dengan konsumsi tahu dan tempe. Sementara itu, konsumsi susu kedua contoh relatif cukup besar, hampir mencapai $100 \mathrm{~g} /$ hari. Contoh gemuk lebih banyak mengonsumsi mie instant, daging ayam, nugget, tahu, fast food dan soft drink dibandingkan contoh normal; sedangkan contoh normal lebih banyak mengonsumsi nasi, telur ayam, ikan dan buah dibandingkan contoh gemuk (Tabel 3).

Hasil uji statistik (Independent Sample t-Test) menunjukkan ada perbedaan nyata dalam mengonsumsi telur ayam antara kedua contoh $(p=0.02)$. Hasil analisis korelasi Spearman juga menunjukan adanya hubungan negatif yang signifikan antara konsumsi telur ayam dengan status gizi contoh $(p=0.002)$. Artinya, konsumsi telur cenderung berkurang pada contoh yang status gizinya mendekati gemuk.

Tabel 3. Intik Konsumsi Pangan Utama berdasarkan Status Gizi

\begin{tabular}{|c|c|c|c|c|c|c|c|c|c|c|c|}
\hline \multirow{4}{*}{ No } & \multirow{4}{*}{ J enis Makanan } & \multicolumn{10}{|c|}{ Asupan Makanan } \\
\hline & & \multicolumn{5}{|c|}{ Normal } & \multicolumn{5}{|c|}{ Gemuk } \\
\hline & & \multirow{2}{*}{$\begin{array}{l}\text { rata-rata } \\
\text { berat }(\mathrm{g})\end{array}$} & \multicolumn{4}{|c|}{ berat $\mathrm{x}$ kandungan dalam DKBM } & \multirow{2}{*}{$\begin{array}{l}\text { rata-rata } \\
\text { berat (g) }\end{array}$} & \multicolumn{4}{|c|}{ berat $\mathrm{x}$ kandungan dalam DKBN } \\
\hline & & & E (kkal) & $P(g)$ & L (g) & KH (g) & & E (kkal) & $\mathbf{P}(\mathbf{g})$ & L (g) & KH (g) \\
\hline \multirow[t]{4}{*}{1} & Makanan Pokok & & & & & & & & & & \\
\hline & Nasi & 346.5 & 657 & 7.8 & 2.1 & 135.9 & 316.9 & 612 & 7.3 & 3.3 & 121.9 \\
\hline & Mie & 26.5 & 126 & 2.6 & 4.8 & 19.2 & 35.3 & 172 & 3.6 & 6.6 & 26.3 \\
\hline & Roti. Sereal & 17.9 & 49 & 1.4 & 0.3 & 10.0 & 17.4 & 50 & 1.5 & 0.4 & 10.1 \\
\hline \multirow[t]{5}{*}{2} & Pangan Hewani & & & & & & & & & & \\
\hline & Ayam & 47.4 & 84 & 5.7 & 6.7 & 0.0 & 50.4 & 90 & 6.1 & 7.1 & 0.0 \\
\hline & Telur ayam & 53.4 & 78 & 6.2 & 5.5 & 0.3 & 28.9 & 42 & 3.3 & 3.0 & 0.2 \\
\hline & Ikan & 13.3 & 22 & 2.8 & 1.2 & 0.4 & 8.1 & 13 & 1.6 & 0.7 & 0.4 \\
\hline & Nugget & 10.9 & 34 & 1.3 & 2.3 & 2.0 & 14.7 & 46 & 1.8 & 3.1 & 2.6 \\
\hline \multirow[t]{3}{*}{3} & Pangan Nabati & & & & & & & & & & \\
\hline & Tahu & 2.0 & 1 & 0.2 & 0.1 & 0.0 & 5.0 & 3 & 0.4 & 0.2 & 0.1 \\
\hline & Tempe & 5.8 & 9 & 1.1 & 0.2 & 0.7 & 6.9 & 10 & 1.3 & 0.3 & 0.9 \\
\hline 4 & Sayur & 20.9 & 5.1 & 0.3 & 0.1 & 1.0 & 23.2 & 7 & 0.4 & 0.2 & 1.1 \\
\hline 5 & Buah & 35.6 & 18 & 0.3 & 0.2 & 4.3 & 25.5 & 11 & 0.2 & 0.0 & 2.6 \\
\hline 6 & Snack & 13.4 & 60 & 1.1 & 4.0 & 7.4 & 13.5 & 66 & 1.2 & 3.6 & 5.1 \\
\hline 7 & Fast Food & 4.4 & 8 & 0.7 & 0.2 & 1.3 & 12.5 & 32 & 1.1 & 0.4 & 5.8 \\
\hline 8 & Soft drink & 42.3 & 19 & 0.1 & 0.1 & 3.6 & 56.6 & 26 & 0.1 & 0.0 & 6.1 \\
\hline 9 & Susu & 92.3 & 142 & 4.4 & 3.4 & 23.9 & 96.3 & 128 & 5.0 & 3.6 & 42.6 \\
\hline
\end{tabular}

Keterangan : $\mathrm{E}=$ energi $($ kkal); $\mathrm{P}=$ protein $(\mathrm{g}) ; \mathrm{L}=$ lemak $(\mathrm{g}) ; \mathrm{KH}=$ Karbohidrat $(\mathrm{g})$ 


\section{KESIMPULAN}

Sebagian besar Ayah dan Ibu contoh berpendidikan Strata 1 (S1). Besar penghasilan ayah kedua kelompok contoh berada pada nilai kurang dari sepuluh juta rupiah sedangkan penghasilan ibu kurang dari tiga juta rupiah. Rata-rata besar pendapatan ayah contoh adalah sebesar Rp $9903750 \pm 9307$ 346, sedangkan rata-rata pendapatan ibu Rp $2503750 \pm$ 3501 950. Hasil uji statistik (Independent Sample t-Test) menunjukkan tidak ada perbedaan yang nyata antara kedua kelompok contoh. Hasil analisis Korelasi Spearman juga menunjukkan tidak adanya hubungan yang signifikan antara tingkat pendidikan dan penghasilan orang tua dengan status gizi contoh.

Sebagian besar contoh normal memiliki tingkat pengetahuan gizi yang rendah; sedangkan pada contoh gemuk memiliki tingkat pengetahuan gizi sedang. Sebagian besar contoh normal dan gemuk memiliki sikap gizi sedang. Hasil analisis Korelasi Spearman menunjukkan tidak adanya hubungan yang signifikan antara tingkat pengetahuan gizi serta sikap gizi dengan status gizi contoh.

Sebagian besar contoh normal ataupun gemuk menyatakan biasa melakukan olahraga. Frekuensi olahraga tersering adalah 2-4 kali dengan durasi/lama waktu berolahraga ratarata 15-30 menit. Kegiatan ekstrakurikuler yang paling banyak diikuti adalah Kelompok Ilmiah Anak (KIA) dan sepak bola. Hasil analisis korelasi Spearman juga menunjukkan tidak adanya hubungan yang signifikan antara frekuensi olahraga, lama berolahraga, dan jenis ekstrakurikuler yang diikuti dengan status gizi contoh $(p>0.05)$.

Snack jenis biskuit adalah yang paling sering dikonsumsi oleh kedua contoh dengan frekuensi 1-3x bulan. Pizza adalah jenis fast food yang paling banyak pernah dikonsumsi oleh kedua contoh dengan frekuensi $1-3 x /$ bulan dan minuman ringan berkarbonasi adalah jenis minuman ringan yang paling sering dikonsumsi oleh kedua kelompok contoh. Hasil analisis Korelasi Spearman menunjukkan tidak adanya hubungan yang signifikan antara kebiasaan mengonsumsi snack, soft drink dan fast food dengan status gizi contoh $(p>0.05)$. Hasil analisis Korelasi Spearman juga menunjukkan tidak adanya hubungan yang signifikan antara kebiasaan mengonsumsi snack, soft drink dan fast food dengan tingkat pengetahuan gizi dan sikap gizi contoh $(p>0.05)$.

\section{DAFTAR PUSTAKA}

[Depkes]. Departemen Kesehatan. 1996. Pedoman Praktis Pemantauan Gizi Orang Dewasa. Departemen Kesehatan Republik Indonesia, Jakarta.

Indraaryani IS. 2009. Konsumsi Fast Food dan Faktor-faktor yang Berhubungan dengan Kegemukan Anak Sekolah di SD Bina Insani. Tesis Program Pascasarjana, Institut Pertanian Bogor, Bogor.

Khomsan A. 2000. Teknik Pengukuran Pengetahuan Gizi. Jurusan Gizi Masyarakat dan Sumberdaya Keluarga, Fakultas Pertanian, Institut Pertanian Bogor, Bogor.

Khomsan A et al. 2009. Aspek Sosio-budaya Gizi dan Sistem Pangan Suku Baduy di Indonesia. Departemen Gizi Masyarakat, Fakultas Ekologi Manusia, Institut Pertanian Bogor - Neys-Van Hoogstraten Foundation, Bogor.

Padmiari Eka IA. 2004. Tingkat Konsumsi Makanan Jajanan pada Anak SD di Kota Denpasar. Tesis Jurusan Gizi dan Kesehatan, Fakultas Kesehatan Masyarakat, Universitas Gajah Mada, Yogyakarta.

Riyadi H. 2003. Metode Penilaian Status Gizi secara Antropometri [diktat]. Jurusan Gizi Masyarakat dan Sumberdaya Keluarga, Fakultas Pertanian, Institut Pertanian Bogor, Bogor.

Rossner S. 2002. The Disease of Twenty-First Century. Jurnal Obesity \& Related Metabolic Disorders. Vol 26,2-4.

Thorpe et al. 2004. Childhood obesity in New York City elementary school students. The American Journal of Public Health 94(9),1496-1500. [20 September 2008]. 